\title{
Real Property Tax Reform. Theoretical Aspects. The Outline of Reference Model for Communes in Poland
}

\author{
PAWEt FeLIS
}

dr hab., Szkoła Główna Handlowa w Warszawie, Instytut Finansów e-mail: pfelis@sgh.waw.pl Research methodology - theoretical-practical study.

Findings - The reform of local taxes should be based on to the theory of optimal taxation and consider the postulates of local finance management. It should also take into account specific features of levies that are important for the local authorities. The article identifies the most significant postulates of the theory of optimal taxation. These include analyzing the system of local taxes in the context of strategic development goals of local authorities, equivalence of benefit exchange between a local government and taxpayers, and minimization of costs of a fiscal process. It was also demonstrated that it is essential to properly legitimize the collection of property taxes.

Originality/value - Indicating the directions of normative changes within the structure of the local tax system.

\section{Teoretyczne aspekty reformowania podatków od nieruchomości - zarys modelu referencyjnego dla gmin w Polsce}

StoWA KLUCZOWE

ABSTRAKT finanse samorządu terytorialnego, podatki lokalne, podatki od nieruchomości, legitymizacja podatków majątkowych

Cel artykułu - Próba systemowego spojrzenia na możliwość racjonalizacji systemu podatków lokalnych.

Metodologia - Badania teoretyczno-praktyczne.

Wynik - Reforma podatków lokalnych powinna uwzględniać postulaty odnoszące się do lokalnej gospodarki finansowej, nawiązywać do teorii optymalnego opodatkowania, ale także brać pod uwagę cechy specyficzne dla danin mających znaczenie dla jednostek lokalnych. Wśród dorobku teorii optymalnego opodatkowania na uwagę zasługują: postrzeganie lokalnego systemu podatkowego w kontekście strategicznych celów rozwojowych jednostek samorządu lokalnego, ekwiwalentność wymiany świadczeń pomiędzy samorządem lokalnym a podatnikiem, minimalizowanie kosztów procesu fiskalnego. Uznano także, że istotna jest właściwa legitymizacja poboru podatków od majątku nieruchomego.

Oryginalność/Wartość - Wskazanie kierunków normatywnych zmian w strukturze lokalnego systemu podatkowego. 


\section{Introduction}

The necessity for a local tax reform in Poland is obvious. The following facts are in favour of it. First, the decentralisation of management which came as a consequence of the process of delegation of certain public tasks to local self-government communities, begun in 1990, requires an appropriate base of local management own funds. If the system of financing of local governments is to function adequately, it is essential to determine suitable sources of revenue as well as to empower them to create their own local policy. Second, to a large extent it is a typical historical system, which has not been subject to a thorough reform yet. The structure of the current tax system was created primarily in the mid-1980s (agricultural tax on land) and at the beginning of 1990s (new forestry tax, a new version of law on taxes and local charges as regulations enacted at the moment the institution of local government was restored). Later, they were followed only by subsequent changes in the construction of taxes aimed at their adjustment to the current socioeconomic situation.

The local tax system is a public finance sector segment which is too important to be subject to coincidental and fragmentary changes. It means a necessity for the construction of a reference model of tax revenue sources of communes in Poland. Its construction requires some reflection from the theoretical perspective as well as critical reflection in relation to the so-far solutions. It is the kind of reflection that this article is devoted to. The concept of normative proposals should undoubtedly account for the determinants of the local financial management and refer to the theory of optimal taxation (boiling down to the following reasoning: the tax combination allowing for the most effective generation of the planned budget revenue), but also to account for some specific features of public taxes significant for local governments.

\section{Rational system of local taxes}

The awareness of the structure of the state system (the state authority of the country and the selfgovernment public-legal entities operating beside it) should indicate the significance of the concept of using institutional and legal solutions, which constitutes the basis of theoretical division into state and local public taxes. Three model approaches to the problem may be distinguished, i.e. the following solutions: (Felis, 2012a):

a) determination of the tax collection points levied with separate state taxes or with local government taxes - the advantage of this idea is an explicit division of taxation objects between the state and the local government, thanks to which every object is taxed only in the sub-system of state or local taxes;

b) the determination of the potential tax collection points connected with different objects without precise principles of division between the state and local government - the disadvantage is a high probability of double taxation of the same objects by the state and local authorities (in the form of separate taxes: state and local taxes imposed on the same object);

c) the determination of potential points connected with different objects from which the active subject, i.e. the state or local government, collects the imposed tax - in the case of such taxes which are a common source of revenue of the state and local government, 
the role of the active subject should be measured with regard to the organisation of imposition, collection, control and enforcement of taxes as well as the method of revenue division.

It seems that the first variant is an optimal solution for the local government and for the coherence of the state tax system. Thanks to self-contained taxes the local government would have a real impact on the generation of their own revenues as well as an opportunity to affect the development of their sources. They do determine the financial independence of local government and contribute to a better implementation of the function of public authority. The prerequisite to achieve such a solution is the necessity for self-financing guarantee for all local government entities.

If the local government financial system is to operate properly, it is indispensable that its essential part, i.e. local taxes, constructed deliberately and rationally, should meet the following goals: (Felis, 2012a):

1. The creation of a long term ability of the local finance sector to finance its services in favour of the local community. It should be remembered though that the science and practice have not managed to determine so far such a division of public revenues to make local revenues universal, absolutely exclusive and, importantly, a completely sufficient source of financing of local government tasks. Ignoring here the circumstances of this state of affairs, let us note that frequently the taxes delegated to local authorities are not fiscally effective, and the system of distribution of the tax sources of the state and local government has not been developed in favour of the latter. The pressure of financial needs is strong in the situation of the growing local government tasks and spending. However, irrespective of this, it is necessary to level the revenue and spending disproportions of every local entity, due to the necessity for the pursuit of the national socio-economic policy of a unitary state, Poland. It should be stated from a pragmatic perspective that in such a situation it will be necessary to implement the state compensation policy, which takes the form of vertical or horizontal redistribution.

2. The support for the local development in the long run and no limitation in the short run. There are always some doubts in the centre of interest about how active the state and local government should be in using public finance tools. Let us emphasize though that theoretically the legitimation of the activity of the public financial system may be indicated by the achievements of the theory of public goods and the imperfectness of the market mechanism.

3. The implementation of essential principles of taxation, i.e. the principle of universality and equality of taxation. The doctrine of taxation has been formulating an opinion that the principle of fairness should constitute the foundation of the taxation system. The idea of imposing the tax burden as a fair part of monetary levy borne in favour of the common weal should account for the universality and equality of taxation. It is well known that these principles, especially the equality of taxation, give rise to interpretation controversies. But it should be emphasized that the principle of fairness makes the taxation system understandable and acceptable (Gomułowicz, Małecki, 1998). 


\section{The outline of the reference model of local tax model}

The reform of local taxes - if it is to be effective - should be pursued in a complex way. In my opinion the concept of reform of the local government tax system in Poland should account for the following elements (Felis, 2012a):

1. The application of selected solutions resulting from the theory of optimal taxation.

2. The necessity for appropriate legitimation of immovable property tax collection.

3. The determination of the scope of competence of communes in local taxes (see more Felis, 2011).

4. The imposition of the ad valorem tax as the only wealth tax on the possessed real property.

5. The reorganisation of the remaining wealth taxes.

\section{The use of the achievements of the theory of optimal taxation}

Within the reform of local tax systems it would be desirable to recognize certain principles derived from the theory of optimal taxation as macroeconomic foundations of a normative taxation model. Its achievements - accounting for the determinants and specific character of the local government - include especially:

1. The perception of a local tax system in the context of strategic development goals of the local government. Thus, it is necessary to enact and obey such tax regulations as to make these taxes allow for the effective source of financing of public needs as well as a stable development of the real sphere.

2. The equivalence of service exchange between the local government and a tax payer taken into consideration. Local communities, accounting for their needs, can most appropriately hierarchize them. Tax burdens borne by the community will not be regarded severe, as those bearing them do it voluntarily for a specific purpose.

3. Remembering about minimising costs of the fiscal process. The level of effectiveness of the tax system as well as its efficiency cannot be determined by the volume of tax revenue. It is not possible to analyse the reasons for the changes in fiscal system effectiveness without taking into account costs generated on different planes. Hence, the improvements in the area of cost minimisation are so important. In order to achieve this it would be desirable to quantify the costs of the fiscal process in the area of the local tax policy.

\section{The necessity for legitimation of movable asset taxation}

When considering the topic of wealth taxes, one cannot ignore the problem of legitimation of their collection as it is about the relation between the fair and economically effective tax systems, i.e. the appropriate relations between the state and a tax payer. These uneasy problems may be expressed in the following aspects:

1. Two rules indicated in the tax doctrine: equivalence of services and proportionality of tax burden according to the payment potential may also be applied to legitimise the real property tax collection. 
2. Manufacturing and provision of public goods at the local level requires appropriate sources of financing. The tax on housing immovable property is a tax having many desirable features which should characterise local taxes.

3. The volume of property tax should result from the level of costs related to the rendering of local public services.

4. The solution which accounts for the value determination of property tax base is compliant with the idea of taxation fairness as it allows for the diversification of the tax burden with regard to the immovable property possessed by the tax payer.

\section{The scope of commune competences in local taxes}

On this plane it is necessary to decide about how wide the scope of legislative commune rights is possible and what socio-economic effects it could bring (see e.g. Kitchen, 2005). The idea of the right to introduce solutions disparate from the statutory ones does seem perfect as radical legislative liberalism could appear harmful, resulting in undesirable phenomena, even distorting the local government activity.

However, if wealth taxes could really be assigned some non-fiscal functions, the local government bodies of public authority should have the right to determine, following their priorities, the volume and form of taxes delegated to local governments in the institutional sense (different tax rates, preferences applied within the jurisdiction of the local government bodies). In an attempt to set desirable directions of changes in the local government finance system in Poland in the legal aspect, we may consider the possibility of selecting one variant from among several indicated by the legislator by local entities.

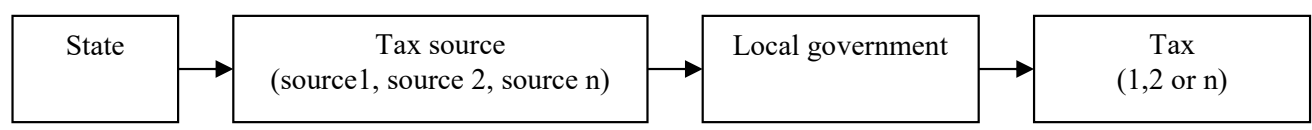

Figure 1. The scope of local government legal independence

Source: author's own materials.

Figure 1 illustrates an acceptable solution to the problem of legal independence of the local government. In this situation the legislative activity of communes would consist in the selection of a tax solution within the tax sources indicated by the national legislator. For example, in the case of real property, communes could decide on their own about imposing taxes indicated in the act of law on the developed property possessed (residential property, non-residential property, business related property, business unrelated property) as well as on undeveloped property (agricultural land, forests and other property).

The suggested solution would, to a certain extent, allow for the adjustment of the system of funding communes to the specific character of the local tax base. However, let us emphasize that in the case of such a solution, it is not enough to think that the local government is guided by clear and rational premises (bearing in mind the principles of fairness and equality of taxation). Apparently, following these principles requires strict regulations and control system. Let us also 
emphasize that a considerable scope of legal independence may give rise to an increased sense of responsibility for the economic situation of local government community. Thus, it is in favour of financial independence.

\section{Ad valorem tax - a tax on all kinds of real property}

The uniformity of real property taxation and adoption of the construction of a new and the only real property tax should be an essential element of real property taxation. Like in the majority of the EU countries the volume of the tax should be based on the value of property. It does not mean, however, that the imitation of tax solutions applied in other countries, and consequently their uniformity is desirable; especially that detailed solutions in this area are diversified (Felis, 2013). There is no doubt that from the perspective of wealth tax systems reform this aspect arouses most controversies. Most researchers claim that the concept of the property value based tax is desirable due to fairness and economic effectiveness of taxation (Etel, 2016; Wójtowicz, 2007). Thus, assuming that fair taxation could result from the tax potential of a tax payer, the fact that people possessing property of a higher value should pay higher taxes should not raise any objection. The solution accounting for the value determination of the tax base allows for the diversification of the volume of tax burdens on the basis of the wealth possessed by the tax payer. Thus, the idea expressed by J. Hozer and S. Kokot is right. They claim that "the essential doctrine of fairness of the cadastral tax is that everybody may become the owner of a property the maintenance of which they can afford" (Hozer, Kokot, 2005, p.136).

The discussion about the issues connected with the future change in the system of property taxation should indicate the following areas (Felis, 2014):

1. The construction and introduction of a complete and coherent cadastral system. The credible property register will allow for the complete identification of the tax base. However, the imposition of cadastral tax cannot be actually confined only to the fiscal aspect. It is possible though to use it multi-functionally in order to support the sustainable economic development of the country (for example to enhance the rights to land, to regulate the property market, to sustainably manage the environment resources and to create and implement land development plans).

2. The procedure of real property universal taxation as a method of universal evaluation of all real property in order to determine its cadastral value. The universal evaluation of cadastral value is a process which determines the cadastral value of many real properties simultaneously. Three parts of this procedure are required (Kowalski, 1994): property classification (division into uniform groups with regard to their usability), estimation (determination of tax value field for each kind of real property), tax zoning (the division of land subject to taxation into areas of similar value). In this process certain mathematical models may be used, for example linear and non-linear regression models, spatial regression models or neural networks (Głuszak, Marona, 2015).

3. Cadastral system management and administration. The creation of the cadastral system is necessary but not sufficient. In the future the cadastral value will be subject to change due to different factors. Hence, the necessity for systematic updating. The negligence in this area (the lack of evaluation or occasional evaluation of real property, rare and 
ineffective control of the state of real property) will decisively reduce the fairness and effectiveness perspective of the ad valorem tax. ${ }^{1}$

4. The role of the local government in developing the constructional elements of the ad valorem tax (see: The scope of competence of communes in local taxes).

\section{The reorganisation of the system of remaining wealth taxes}

A necessary synchronisation of transformations in the system of remaining wealth taxes is a separate problem. The most important issues include:

a) the unification of the scope of legislative rights of commune councils with regard to all taxes delegated as a whole to communes (primarily inheritance tax, donation tax and tax on civil law transactions);

b) the unification of the principles of donation taxes through the inclusion of all donations in the tax on inheritance and donations or in the income tax (currently there is a subject diversification of funds obtained from donations);

c) the removal of unnecessary wealth taxes and charges from the system after the imposition of the ad valorem tax (agricultural tax, forestry tax, betterment levy or planning levy);

d) the adoption of an ultimate model of farm taxation (lifting separate taxation of farmers and taxing them based on general principles, i.e. income tax, VAT as well as wealth tax on the real property value or further application of specific principles, different from those in the remaining EU countries);

e) the reorganisation of the current system of tax preferences and reducing them to those which may really be treated as instruments of commune fiscal policy to stimulate the development of local entrepreneurship (a positive example is found in the solutions applied by some EU countries within taxes on inheritance and donations treated as an important element of support for the intergenerational business succession); such activities will certainly simplify all the taxes and, consequently, reduce costs of tax adjustment;

f) the consideration of imposition of ecological taxes, which would primarily perform an allocation function.

\section{Final observations}

The reform of local taxes in Poland should objectively be considered to be complex and difficult to implement. It is the quality transformations of the local tax system that are indispensable, and not subsequent "cosmetic treatment" of the construction of selected taxes. It seems that it could significantly enhance the system of local taxes through their increased role in the structure of commune budgets and the use of their non-fiscal function to support and stimulate the local growth. The concept of rational local tax system formulated for years by theoreticians and practitioners is a chance to raise the significance of the local tax policy.

1 This problem has appeared in some EU countries, among others in Germany and France. For example, in Germany the tax value of economic goods does not reflect properly the real value of a real estate. See more: Spengel, Heckemeyer, Zinn, 2011. 
The review of issues related to the process of implementation of the tax on the value of real property proves that the success of its implementation will entirely depend on the basic elements indicated in the article, i.e. an efficient system of universal taxation of real property and well balanced tax volume but also on the socio-economic conditions. The changes should be adequately spread over time (the necessity for advance change announcements) and legitimised in such a way as to be accepted by the tax payers.

\section{References}

Etel, L. (2016). Opodatkowanie nieruchomości - kierunki pożądanych zmian. In: H. Dzwonkowski, J. Kulicki (eds.), Dylematy reformy systemu podatkowego w Polsce. Warszawa: Wydawnictwo Sejmowe.

Felis, P. (2011). The Financial Independence of Local Self-Government Units in the Acquisition of Sources to Finance Their Activity - The challenges for Self-Government Theory and Practice. Journal of Management and Financial Sciences, 6 (IV).

Felis, P. (2012a). Elementy teorii i praktyki podatków majątkowych. Poszukiwanie ładu w opodatkowaniu nieruchomości $w$ Polsce z perspektywy przedsiębiorców oraz jednostek samorządu terytorialnego. Warszawa: SGH.

Felis, P. (2012b). Teoretyczne i praktyczne aspekty reformowania systemu podatków lokalnych w Polsce. In: R. Bartkowiak, J. Ostaszewski (eds.), Dorobek ekonomii, finansów i nauk o zarządzaniu oraz jego praktyczne wykorzystanie na przełomie XX i XXI wieku. Warszawa: SGH.

Felis, P. (2013). Podatki od nieruchomości w wybranych krajach UE. Studia i Prace KZiF. Zeszyty Naukowe SGH, 126.

Felis, P. (2014). Theoretical and Practical Aspects of the Real Estate Taxation System Reform in Poland - An Outline of the Concepts of the Target Solution. Journal of Management and Financial Sciences, 15 (VII).

Felis, P. (2015). Podatki od nieruchomości a polityka podatkowa gmin w Polsce. Warszawa: SGH.

Gomułowicz, A., Małecki, J. (1998). Podatki i prawo podatkowe. Wyd. III - zaktualizowane i rozszerzone, Poznań: Wyd. Ars boni et aequi.

Głuszak, M., Marona, B. (2015). Podatek katastralny. Ekonomiczne uwarunkowania reformy opodatkowania nieruchomości. Warszawa: Poltext.

Grądalski, F. (2005). Teoretyczne i praktyczne aspekty rachunku kosztów fiskalizmu - przykład Polski. In: W. Pacho (ed.), Szkice ze współczesnej teorii ekonomii. Warszawa: SGH.

Grądalski, F. (2006). System podatkowy w świetle teorii optymalnego opodatkowania. Warszawa: SGH.

Hozer, J., Kokot, S. (2005). Problemy powszechnej taksacji nieruchomości w Polsce. Zeszyty Naukowe Uniwersytetu Szczecińskiego, 415, Prace Katedry Ekonometrii i Statystyki, 16.

Kitchen, H., (2005). Property Taxation: Issues in Implementation. Working Paper, 3. Kingston: Queen's University.

Kowalski, G. (1994). Rola i miejsce stref taksacyjnych w modelu powszechnej taksacji nieruchomości na obszarach zurbanizowanych. In: S. Przewłocki (ed.), Model ustalania i weryfikacji zasięgu stref taksacyjnych dla potrzeb powszechnej taksacji nieruchomości. Łódź: Wydawnictwo Politechniki Łódzkiej.

Spengel, Ch., Heckemeyer, J.H., Zinn, B. (2011). Reform der Grundsteuer: Ein Blick nach Europa. Der Betrieb, 1.

Wójtowicz, K. (2007). System opodatkowania nieruchomości w Polsce. Lublin: Uniwersytet Marii Curie-Skłodowskiej.

\section{Cytowanie}

Felis, P. (2017). Real property tax reform. Theoretical aspects. The outline of reference model for communes in Poland. Współczesne Finanse. Teoria i Praktyka, 1 (2), 5-12. DOI: 10.18276/wf.2017.1-01. 